\title{
Relatedness within and among northern long-eared bat (Myotis septentrionalis) colonies at a local scale
}

\author{
Miluska Olivera-Hyde, Alexander Silvis, Eric M. Hallerman, W. Mark Ford, and Eric R. Britzke
}

\begin{abstract}
We assessed parentage within and among maternity colonies of northern long-eared bats (Myotis septentrionalis (Trouessart, 1897)) in north-central Kentucky, USA, from 2011 to 2013 to examine colony social structure, formation, and membership dynamics. We intensively sampled colonies in close and remote $(>10 \mathrm{~km})$ proximity before and after targeted day-roost removal. Colonies were not necessarily composed of closely related individuals, although natal philopatry was common. Adjacent colonies often contained maternally related individuals, indicating that some pups did disperse, albeit not far from their natal home range. Whereas some young had been sired by males also collected on site, most had not, as would be expected since the species mates in fall near hibernacula across a wider landscape. The number of parentages that we inferred among colonies, however, suggests that outside the maternity season, social groups may be relatively flexible and open. Analysis of microsatellite DNA data showed a low $F_{S T}(0.011)$ and best fit to a model of one multilocus genotypic cluster across the study area. We observed high turnover in colony membership between years in all colonies, regardless of roost-removal treatment. Our results suggest that female northern long-eared bats exhibit fidelity to a general geographic area and complex, dynamic social-genetic structure.
\end{abstract}

Key words: social network, colony structure, maternity colony, relatedness, roost loss, northern long-eared bat, Myotis septentrionalis.

Résumé : Nous avons évalué la filiation au sein de colonies de parturition de vespertilions nordiques (Myotis septentrionalis (Trouessart, 1897)) et entre elles, dans le centre nord du Kentucky (États-Unis), de 2011 à 2013, afin d'examiner la structure sociale, la formation et la dynamique de la composition de ces colonies. Nous avons procédé à l'échantillonnage intensif de colonies proches et éloignées $(>10 \mathrm{~km})$ avant et après le retrait ciblé de gîtes diurnes. Les colonies n'étaient pas nécessairement composées d'individus étroitement reliés, même si une philopatrie natale était courante. Des colonies contiguës contenaient souvent des individus présentant une filiation maternelle, ce qui indique une certaine dispersion des jeunes, bien que pas très loin de leur domaine vital natal. Alors que certains jeunes avaient pour pères des mâles aussi échantillonnés sur place, il n'en allait pas ainsi pour la plupart, conformément aux attentes étant donné que l'espèce s'accouple à l'automne près d'hibernaculums dispersés sur un plus grand territoire. Le nombre de liens de filiation inférés entre colonies donne toutefois à penser que, en dehors de la période de parturition, les groupes sociaux peuvent être relativement souples et ouverts. L'analyse de données d'ADN microsatellite donne un $F_{\mathrm{ST}}$ faible $(0,011)$ et le meilleur ajustement à un modèle intégrant un seul groupement génotypique multilocus dans la région à l'étude. Nous avons observé un fort renouvellement interannuel de la composition de la colonie pour toutes les colonies, quel que soit le traitement de retrait de gîtes diurnes. Nos résultats indiqueraient que les vespertilions nordiques femelles sont fidèles à une région géographique générale et qu'elles présentent une structure sociogénétique dynamique et complexe. [Traduit par la Rédaction]

Mots-clés : réseau social, structure de la colonie, colonie de parturition, filiation, disparition de gîtes diurnes, vespertilion nordique, Myotis septentrionalis.

\section{Introduction}

For many mammalian species, social groups provide benefits to fitness through positive effects upon adult survival or recruitment of young. Although genetic relatedness is not essential for social interactions, cooperation is favored through kin selection when interacting individuals are related (Marshall 2011; Frank 2013). However, indirect fitness benefits can be important even for groups with low relatedness among members (Queller 2011). Despite striking ecological differences in life strategies, many bat species are highly social (Bradbury 1977; Kerth 2008). Formation of maternity colonies, which consist primarily of reproductive fe- males and their offspring, is particularly common. Maternity colonies may help minimize the physiological stress of lactation (Watkins and Shump 1981; Wilde et al. 1999), create more favorable thermal conditions in the maternity roost (Willis and Brigham 2007), or permit cooperative rearing of young (Jennions and Macdonald 1994; Kerth and Konig 1999; Kerth 2008). In a number of temperate bat species that form maternity colonies, frequent individual movements among numerous roosts creates a fission-fusion social dynamic (Kerth and Konig 1999; Willis and Brigham 2004; Rhodes 2007; Popa-Lisseanu et al. 2008). This social dynamic is characterized by "fusions" of dispersed individuals

Received 22 August 2018. Accepted 9 January 2019.

M. Olivera-Hyde, A. Silvis, and E.M. Hallerman. Department of Fish and Wildlife Conservation, Virginia Tech, Blacksburg, VA 24061, USA. W.M. Ford. U.S. Geological Survey Virginia Cooperative Fish and Wildlife Research Unit and Department of Fish and Wildlife Conservation, Virginia Tech, Blacksburg, VA 24061, USA.

E.R. Britzke. U.S. Army Corps of Engineers Engineer Research and Development Center, Environmental Laboratory, Vicksburg, MS 39180, USA.

Corresponding author: Eric M. Hallerman (email: ehallerm@vt.edu).

This work is free of all copyright and may be freely built upon, enhanced, and reused for any lawful purpose without restriction under copyright or database law. The work is made available under the Creative Commons CC0 1.0 Universal Public Domain Dedication (CC0 1.0). 
into groups and subsequent "fissions" of groups into smaller, dispersed groups or individuals (Kummer 1971; Aureli et al. 2008). Several mechanisms contributing to the development of societies with fission-fusion dynamics over long time scales have been proposed (Aureli et al. 2008), but the proximate factors linked to these dynamics, including relatedness among individuals within colonies, often are unclear or speculative. Nonetheless, elucidation of these social and genetic factors is important for understanding species' ecology critical for the development of effective conservation strategies.

The northern long-eared bat (Myotis septentrionalis (Trouessart, 1897)) is a useful model study system to explore proximate factors related to fission-fusion social dynamics, as the species has been well studied relative to other temperate bat species (Silvis et al. 2016a, 2016b). During summer, female northern long-eared bats form maternity colonies of between 10 and 100 females in trees or snags having internal cavities within forested environments (Silvis et al. 2016b), with each female giving birth to one offspring (Caceres and Barclay 2000). Colonies occupy networks of trees that may exist in close spatial proximity $(<1 \mathrm{~km}$ between roosting area centroids; Silvis et al. 2015b), but individuals apparently do not share roosts with individuals from other colonies, and colonies have spatial footprints that are consistent between years (Silvis et al. 2014). Fission-fusion dynamics within colonies are characterized as roost switching and sharing during the maternity season (Garroway and Broders 2007; Patriquin et al. 2010; Johnson et al. 2012a; Silvis et al. 2014), and individuals within colonies maintain different temporal associations, including both short-term and long-term acquaintances (Garroway and Broders 2007). General site fidelity has been observed (Perry 2011), although fidelity to roosting or foraging areas has not been fully assessed.

Social network structure in northern long-eared bat maternity colonies varies temporally in relation to age and reproductive period, with lactating bats forming larger and more stable groups and using fewer roosts (Patriquin et al. 2010; Silvis et al. 2014, $2015 b$ ). Roost and ambient weather conditions influence roostswitching behavior, and therefore may affect social dynamics (Patriquin et al. 2016). Roost availability also may influence switching dynamics and social structure in some temperate and tropical bat species (Chaverri 2010; Johnson et al. 2012b), but no clear relationship between roost availability and colony social structure has been established in northern long-eared bats (Silvis et al. 2014; Ford et al. 2016).

Advances have been achieved in understanding of genetic structure within and among northern longeared bat colonies (Patriquin et al. 2013), as well as the genetic structure of social groups of other temperate bats that display a fission-fusion dynamic, including Bechstein's bat (Myotis bechsteinii (Kuhl, 1817)) (Kerth et al. 2002b), greater horseshoe bat (Rhinolophus ferrumequinum (Schreber, 1774)) (Rossiter et al. 2002), and big brown bat (Eptesicus fuscus (Palisot de Beauvois, 1796)) (Metheny et al. 2008b). Analysis of mitochondrial DNA suggests that northern long-eared bats within colonies are related maternally and that preferential association occurs with close relatives (Patriquin et al. 2013). However, females within colonies may not be more closely related to one another than they are to individuals from neighboring colonies (Patriquin et al. 2013). This contrasts with other species of temperate bats globally, where greater levels of relatedness within than among colonies, or among preferentially associating pairs at the maternal level, have been observed (Wilkinson 1985; Kerth and Konig 1999; Kerth et al. 2011).

Understanding patterns of relatedness within and among colonies will be informative in uncovering how maternity colonies form and organize spatially. For example, high relatedness among neighboring colonies, but higher levels of relatedness within colonies, may suggest that new colonies form by "budding" as individual matrilines leave the colony to form new colonies. In contrast, low relatedness within and among colonies may suggest that initial colony formation occurs before bats reach maternity sites, or that colony formation occurs as individuals scattered across the landscape coalesce into groups around high-quality roosting resources. Previous research on northern long-eared bats has found marked differences in roost selection among regions (Owen et al. 2002; Perry and Thill 2007; Garroway and Broders 2008; Johnson et al. 2009), as well as differences in roosting behavior (Patriquin et al. 2016). Differences in relatedness within and among colonies among regions may highlight differential pressures of habitat, environmental perturbation, or weather on colony membership and formation.

Although genetic structuring of colonies in northern longeared bats is not yet well understood, basic aspects of population structure have been resolved. Behavioral and genetic data indicate that mating takes place during the fall pre-hibernation period when large numbers of cavernicolous bats migrate to and congregate around hibernacula (Barbour and Davis 1969; Veith et al. 2004; Rivers et al. 2005). This mating behavior broadens the spatial extent of gene flow in cavernicolous bats (Arnold 2007) and reduces local genetic differentiation. Concordant with the expectation based on the biology of other cavernicolous bats, groups of northern long-eared bats are indistinguishable at the regional to continental geographic scale using nuclear markers (Johnson et al. 2014).

The primary goal of our study was to characterize colonies using molecular genetic markers from both mitochondrial (maternally transmitted) and nuclear (biparentally transmitted) genomes in a well-studied population of northern long-eared bats. In this context, our hypotheses regarding colony structure were

- $\mathrm{H}_{1}$ : colonies comprised unrelated females and their young. Evidence supporting this hypothesis are colonies with multiple mitochondrial DNA haplotypes and nuclear markers with little between-colony differentiation.

- $\mathrm{H}_{2}$ : colonies comprised related females. Supporting evidence would be each colony being dominated by one mitochondrial haplotype and nuclear markers showing considerable betweencolony differentiation.

Because we took tissue samples from pups after weaning, our hypotheses regarding pup dispersal were

- $\mathrm{H}_{1}$ : female pups stay in their natal colony. Supporting evidence would be localization of inferred mother-pup pairs within the same colonies following their birth year.

- $\mathrm{H}_{2}$ : female pups disperse from their natal colony. Supporting evidence would be inferred mother-pup pairs not being localized within the same colonies following their birth year.

Secondarily, we tested hypotheses regarding the effects of roost-tree cutting and subsequent turnover of colony membership:

- $\mathrm{H}_{1}$ : individual bats from a broad area opportunistically occupy newly treated areas. Supporting evidence would be lower relatedness within colonies and between neighboring colonies than observed pre-treatment.

- $\mathrm{H}_{2}$ : individual bats from neighboring colonies opportunistically occupy newly treated areas. Supporting evidence would be unchanged relatedness values.

- $\mathrm{H}_{3}$ : an existing colony in suboptimal habitat occupies newly treated areas. Supporting evidence would be relatedness within that colony being similar to those in other colonies, as well as low relatedness to other colonies.

\section{Materials and methods}

\section{Study site}

We conducted our study on the Fort Knox military reservation in Meade, Bullitt, and Hardin counties, Kentucky, USA $\left(37.9^{\circ} \mathrm{N}\right.$, 
Fig. 1. Left two panels from top to bottom show the location of Fort Knox within Kentucky, USA, and the general location of bat captures on Fort Knox, 2011-2013. Right two panels show roosting areas of northern long-eared bat (Myotis septentrionalis) maternity colonies over the study period by year.

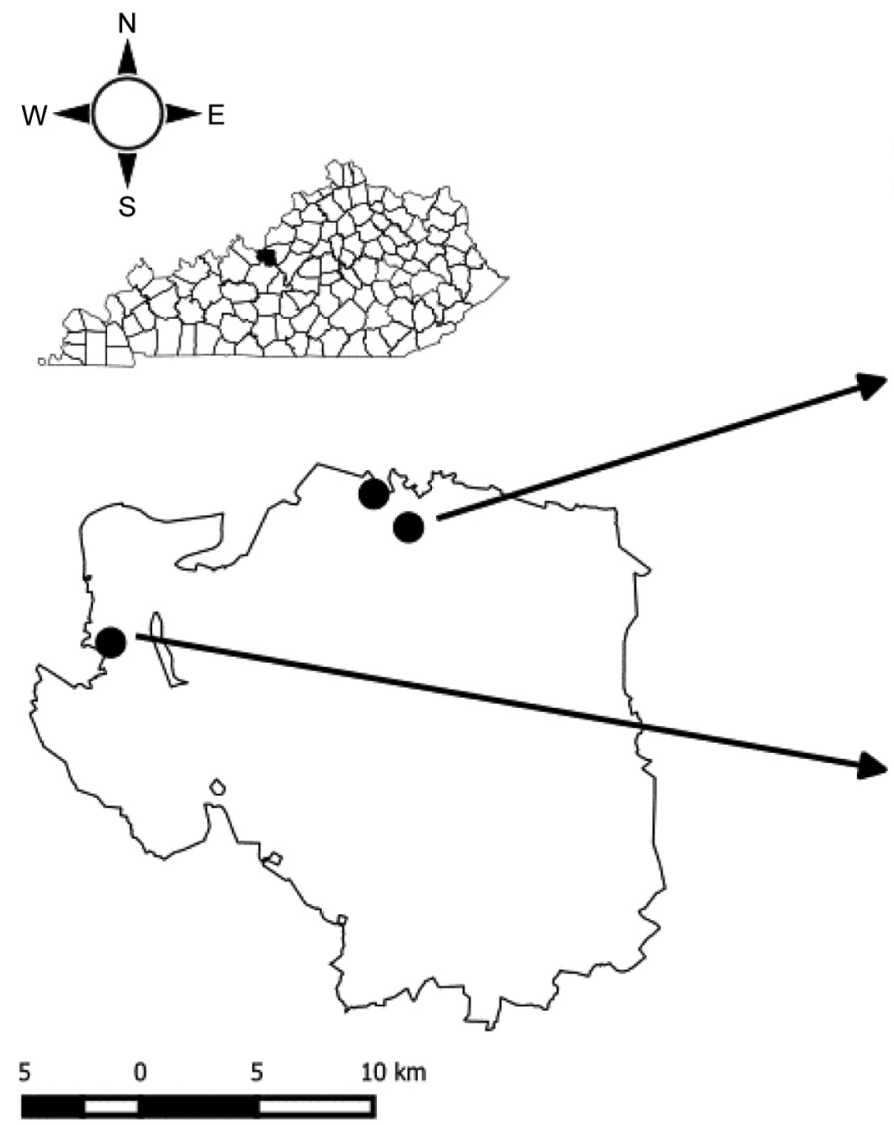

$-85.9^{\circ} \mathrm{E}$; WGS84), from May through July 2011-2013 (Fig. 1); the maximum distance between sample locations on the reservation is $15 \mathrm{~km}$. Our sites were in the Western Pennyroyal subregion of the Mississippian portion of the Interior Low Plateau physiographic province (Arms et al. 1979). Forest cover was predominantly a western mixed - mesophytic association, with older (>80 years) second- and third-growth forests that regenerated from old-field abandonment that were dominated by white oak (Quercus alba L.), black oak (Quercus velutina Lam.), chinkapin oak (Quercus muehlenbergii Engelm.), shagbark hickory (Carya ovata (Mill.) K. Koch), yellow poplar (Liriodendron tulipifera L.), white ash (Fraxinus americana L.), and American beech (Fagus grandifolia Ehrh.) in the overstory. Forest understory species included sassafras (Sassafras albidum (Nutt.) Nees), redbud (Cercis canadensis L.), and sugar maple (Acer saccharum Marsh.). Bats selected roosts that were primarily in shaded, growth-suppressed sassafras with cavities (Silvis et al. 2015a).

\section{Sample collection}

We captured northern long-eared bats over small woodland pools or at known roosts using mist nets during early and midsummer before pup volancy and dispersal. We attached a radio transmitter (LB-2, $0.31 \mathrm{~g}$; Holohil Systems Ltd., Woodlawn, Ontario, Canada) between the scapulae of each adult female bat using Perma-Type surgical cement (Perma-Type Company Inc., Plainville, Connecticut, USA) and issued a uniquely numbered lipped band (Porzana, Ltd., Icklesham, East Sussex, UK) to the forearm of all captured bats. We took a $3 \mathrm{~mm}$ biopsy punch from the plagiopatagium of each wing near the body while avoiding veins and arteries. We fixed biopsy punches in $90 \%$ ethanol. Cap-
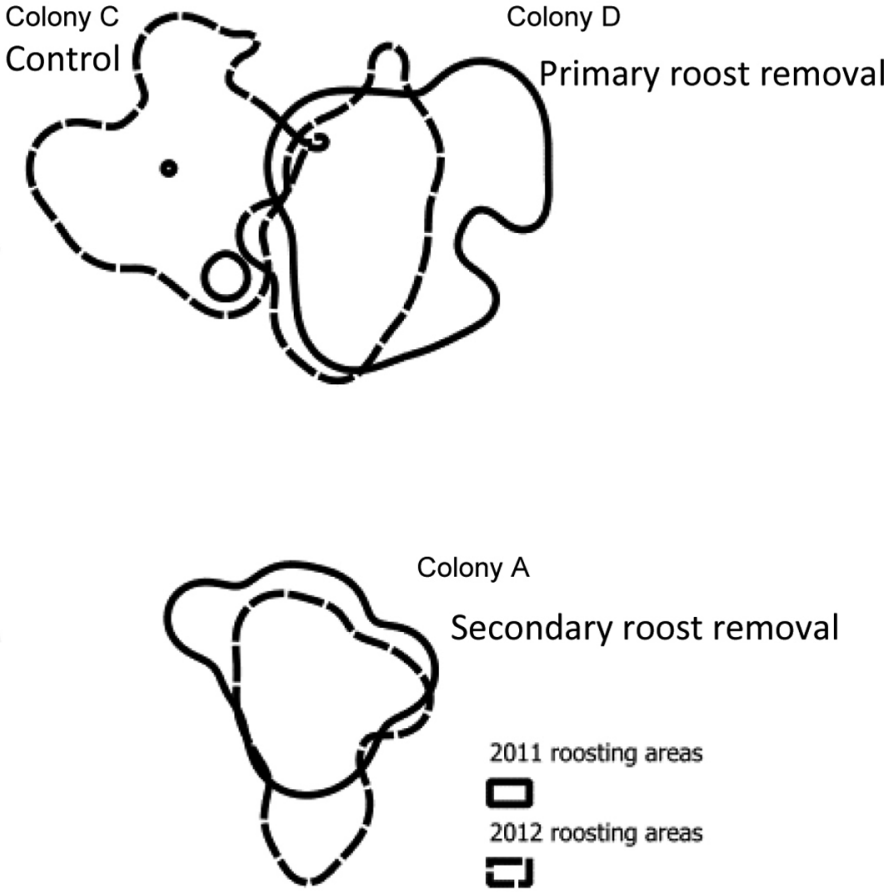

Colony A

Secondary roost removal

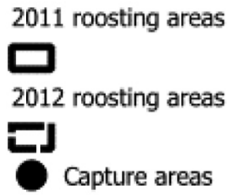

$200 \quad 0 \quad 200 \quad 400 \mathrm{~m}$

tured bats were released within $30 \mathrm{~min}$ of capture at the net site. After identifying a small number of female roosts using radiotelemetry, we maximized the number of female bats captured by erecting mist nets around located roosts. This study was carried out in accordance with state requirements for capture and handling of wildlife (Kentucky Department of Fish and Wildlife Resources permit numbers SC1111108, SC1311170, and SC1311169). The capture and handling protocol followed the guidelines of the American Society of Mammalogists (Sikes and Gannon 2011) and was approved by the Virginia Polytechnic Institute and State University Institutional Animal Care and Use Committee (protocol number 11-040-FIW).

\section{Colony identification and habitat manipulation}

Colony identification and membership was previously assigned to all individuals by Silvis et al. (2014) in an analysis of roost switching and coincident roost use by northern long-eared bats captured at our sites; Silvis et al. (2014) identified five maternity colonies of northern long-eared bats in 2011 and documented roost network characteristics from roost-switching behavior. Subsequently, Silvis et al. (2015b) implemented two roost-removal treatments in February of 2012 (for the three largest colonies of the five identified colonies in 2011) and re-documented social structure. In the first roost-removal treatment, the roost with the maximum degree of centrality, i.e., the roost most used by the most bats at some time for the maternity season in the roost network, was removed (hereafter primary removal), whereas in the second treatment, five randomly selected roost trees of less than the maximum degree of centrality were removed (hereafter secondary removal). Additionally, a control colony for which no 
Table 1. Microsatellite DNA properties, methods, and variation for a northern long-eared bat (Myotis septentrionalis) population at Fort Knox, Kentucky, USA, 2011-2013.

\begin{tabular}{lllllllll}
\hline Locus & $\begin{array}{l}\text { Repeat } \\
\text { motif }\end{array}$ & $\begin{array}{l}\text { Size range } \\
(\mathrm{bp})\end{array}$ & $\begin{array}{l}\mathrm{T}_{\mathrm{A}} \\
\left({ }^{\circ} \mathrm{C}\right)\end{array}$ & $\begin{array}{l}\text { No. of alleles } \\
\text { per locus }\end{array}$ & $\begin{array}{l}\mathrm{H}_{\mathrm{o}} \\
\mathrm{H}_{\mathrm{e}}\end{array}$ & $\begin{array}{l}\text { Null allele } \\
\text { frequency }\end{array}$ & References \\
\hline MmyE24 & $(\mathrm{TC})_{32}$ & $176-244$ & 54 & 27 & 0.71 & 0.92 & 0.106 & Castella and Ruedi 2000 \\
MmyF19 & $(\mathrm{CA})_{19}$ & $188-232$ & 54 & 23 & 0.95 & 0.92 & None & Castella and Ruedi 2000 \\
MmyG9 & $(\mathrm{TC})_{19}$ & $128-178$ & 54 & 22 & 0.89 & 0.94 & 0.021 & Castella and Ruedi 2000 \\
MmyD15 & $(\mathrm{AC})_{17}$ & $70-148$ & 54 & 34 & 0.77 & 0.95 & 0.088 & Castella and Ruedi 2000 \\
MmyB15 & - & $108-174$ & 47 & 33 & 0.92 & 0.96 & None & Kerth et al. 2002a, 2002b \\
EFuF6 & $(\mathrm{GT})_{20}$ & $160-246$ & 47 & 26 & 0.72 & 0.88 & 0.081 & Vonhof et al. 2002 \\
\hline
\end{tabular}

Note: $\mathrm{T}_{\mathrm{A}}$ is annealing temperature, $H_{\mathrm{o}}$ is observed heterozygosity, and $H_{\mathrm{e}}$ is expected heterozygosity.

roosts, either primary or secondary, were removed was retained for sampling. Full details for colony identification and social network characteristics are provided in Silvis et al. (2014) and Silvis et al. (2015b).

\section{Mitochondrial methods}

We extracted DNA using the DNeasy® Blood \& Tissue Kit (Qiagen) and quantified double-stranded DNA (dsDNA) using a $\mu$ Lite PC spectrophotometer (BioDrop, Cambridge, UK). To amplify a $311 \mathrm{bp}$ fragment of the mitochondrial D-loop, we used primers L16517 (Fumagalli et al. 1996) and Meth-R (Fumagalli et al. 1996; Metheny et al. 2008a). Polymerase chain reaction (PCR) amplification was conducted in a volume of $22 \mu \mathrm{L}$ containing $0.67 \times$ GoTaq Flexi Buffer, $3.33 \mathrm{mmol} / \mathrm{L} \mathrm{MgCl}_{2}, 0.07 \mathrm{mmol} / \mathrm{L}$ dNTPs, $0.03 \mathrm{mg} / \mathrm{mL}$ BSA, $0.05 \mu \mathrm{mol} / \mathrm{L}$ of each primer, $0.03 \mathrm{U} / \mu \mathrm{L}$ GoTaq ${ }^{\circledR}$ DNA polymerase (Promega), and $5-50 \mathrm{ng} / \mu \mathrm{L}$ of dsDNA. PCR was performed by using either a $\mathrm{T}_{100}{ }^{\mathrm{TM}}$ or a MyCycler ${ }^{\mathrm{TM}}$ thermocycler (both from Bio-Rad). The PCR protocol was $94{ }^{\circ} \mathrm{C}$ for $3 \mathrm{~min}$, followed by 35 cycles of $94^{\circ} \mathrm{C}$ for $1 \mathrm{~min}, 54^{\circ} \mathrm{C}$ for $1 \mathrm{~min}$, and $72^{\circ} \mathrm{C}$ for $1 \mathrm{~min}$ and $30 \mathrm{~s}$ (extension), with a final extension at $72{ }^{\circ} \mathrm{C}$ for $5 \mathrm{~min}$ and a hold at $4{ }^{\circ} \mathrm{C}$. Upon completion of PCR, $7 \mu \mathrm{L}$ of the PCR product was mixed with $3 \mu \mathrm{L}$ loading dye and loaded into a $2 \%$ agarose TBE gel and subjected to electrophoresis at $100 \mathrm{mV}$ for $40 \mathrm{~min}$. Samples with successful PCR amplification presented a band of $311 \mathrm{bp}$. The PCR-positive samples were purified using the QIAquick ® PCR Purification Kit (Qiagen), which resulted in a final volume of $50 \mu \mathrm{L}$. DNA concentration was calculated with a BioDrop spectrophotometer and varied from 3 to $40 \mathrm{ng} / \mu \mathrm{L}$. PCR amplification products were sequenced using the BigDye Terminator Cycle Sequencing Kit version 3.1 on an ABI3730 DNA sequencer at the Virginia Biocomplexity Institute (Blacksburg, Virginia, USA).

We edited mitochondrial D-loop sequences and sequence alignments using Geneious version 7.1.5 (Biomatters, Inc., San Francisco, California, USA). We used DnaSP version 5.10 (Rozas et al. 2009) to identify polymorphic sites and quantify numbers of respective haplotypes. We created a haplotype network using the TCS network inference method in program PopArt (Leigh and Bryant 2015).

\section{Microsatellite DNA analysis}

We analyzed variation at six northern long-eared bat microsatellite DNA loci using primers developed by Castella and Ruedi (2000), Kerth et al. (2002a), and Vonhof et al. (2002) using the PCR conditions presented in Table 1 . We estimated amplicon sizes by comparing the mobilities of amplification products relative to the GeneScan $^{\mathrm{TM}} \mathrm{LIZ500}^{\mathrm{TM}}$ dye molecular weight size standard (Life Technologies) using an ABI3730 DNA sequencer at the Virginia Biocomplexity Institute. We scored amplification products using GeneMarker version 2.6.3 (SoftGenetics, State College, Pennsylvania, USA).

We tested all microsatellite loci for evidence of null alleles and scoring error due to stutter or large allele dropout using a Monte Carlo simulation of expected allele size differences implemented in MicroChecker version 2.2.3 (Van Oosterhout et al. 2004); frequencies of null alleles were estimated following the method of
Brookfield (1996). We conducted an analysis of molecular variance (AMOVA; Weir and Cockerham 1984; Excoffier et al. 1992; Weir 1996) for all individuals assigned to colonies using Arlequin version 3.5 (Excoffier and Lischer 2010) with 1000 permutations to partition molecular variation into within-colony and betweencolony components and to estimate the population differentiation metric, i.e., the fixation index $\left(F_{\mathrm{ST}}\right)$.

Because we could determine age class as adults or young of the year from the ossification of the epiphyseal gap of the fourth metacarpal (Anthony 1988), but not specific age of bats, we were unable to determine exact genealogies. Instead, from our microsatellite DNA data, we used program Cervus (Kalinowski et al. 2007) to assess the possibility of parentage relationships among individuals. To be considered a candidate mother, that individual had to have the same mitochondrial type as a focal individual. We assessed the likelihood for true parentage as the ratio for the candidate parent being the true parent divided by the likelihood that the candidate parent is not the true parent, represented as a LOD (log of the odds ratio) score. Under this calculation, a positive LOD score means that the candidate parent is more likely to be the true parent than not the true parent. LOD scores cannot be evaluated using a standard distribution such as the $\chi^{2}$ distribution; hence, Cervus uses simulation of parentage analysis to evaluate the confidence in assignment of parentage to the most likely candidate parent. To ensure satisfactory confidence in individual parentage assignments, we report only those assignments associated with 95\% confidence in Cervus output.

To assess population structure among individuals belonging to any of the five colonies during the 3 years, we used Structure (Pritchard et al. 2000) to perform a cluster analysis of multilocus genotypes and compared results from 20 independent runs to each value of $k$ from 1 to 12 clusters. All Structure models allowed for background admixture and correlation of allele frequencies among clusters, and searched parameter space following a burn-in of 100000 iterations and 1000000 Markov chain Monte Carlo repetitions after burn-in. We retained the replicate with the most likely Bayesian deviance score ( -2 log-likelihood) as the best estimate of the likelihood of that $k$ value (Pritchard et al. 2000). We did not apply the Evanno et al. (2005) model because it is not effective for cases where $k=1$.

\section{Results}

\section{Field data}

From the five maternity colonies identified by Silvis et al. (2014, 2015a) (colonies A-E), we captured 79 northern long-eared bats (63 female, 16 male) in 2011, 93 (72 female, 21 male) in 2012, and 19 (11 female, 8 male) in 2013. As reported by Silvis et al. (2015a), the number of bats captured varied among colonies, but based on roost exit counts, between $60 \%$ and $100 \%$ of individuals were captured per colony (Table 2 ). We recaptured three individuals in multiple years. We captured a number of individuals that occurred within or near identified colony areas during 2011 and 2012 but were not observed to share roosts with colony members; these bats were not assigned to any colony (hereafter non- 
Table 2. Size and sampling intensity for five maternity colonies of northern long-eared bats (Myotis septentrionalis) at Fort Knox, Kentucky, USA, 2011-2013.

\begin{tabular}{|c|c|c|c|c|c|c|c|c|c|c|}
\hline & \multicolumn{2}{|c|}{ Colony A } & \multicolumn{2}{|c|}{ Colony B } & \multicolumn{2}{|c|}{ Colony C } & \multicolumn{2}{|c|}{ Colony D } & \multicolumn{2}{|c|}{ Colony E } \\
\hline & 2011 & 2012 & 2011 & 2012 & 2011 & 2012 & 2011 & 2012 & 2011 & 2012 \\
\hline Minimum colony size & 13 & 24 & 5 & 5 & 18 & 20 & 14 & 25 & 2 & - \\
\hline Number of bats captured & 8 & 23 & 2 & 2 & 15 & 14 & 13 & 25 & 2 & - \\
\hline
\end{tabular}

Note: Sampling access to colony E was lost during summer of 2011 and the colony was not revisited after initial captures. Following arrival of White-nose Syndrome

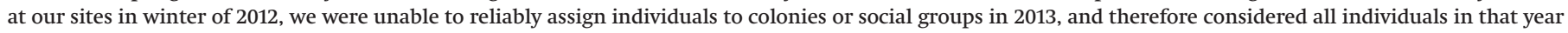
unassigned.

Table 3. Mitochondrial DNA haplotypes of northern long-eared bats (Myotis septentrionalis) at Fort Knox, Kentucky, USA, $2011-2013$.

\begin{tabular}{|c|c|c|c|c|c|c|c|c|c|c|c|c|c|c|c|c|c|c|c|c|c|c|c|c|c|c|c|}
\hline Haplotype & $N$ & \multicolumn{26}{|c|}{ Nucleotide position } \\
\hline Mysep1 & 1 & $\mathrm{~T}$ & $\mathrm{~T}$ & $\mathrm{C}$ & $\mathrm{C}$ & $\mathrm{T}$ & $\mathrm{C}$ & A & A & A & G & G & G & G & G & G & A & A & $\mathrm{C}$ & A & A & G & G & G & A & G & A \\
\hline Mysep3 & 1 & . & G & A & A & $\mathrm{Z}$ & G & . & G & G & . & . & . & $\mathrm{T}$ & . & . & G & . & . & . & . & . & . & . & . & A & . \\
\hline Mysep4 & 1 & . & . & . & . & . & . & G & G & G & A & . & . & . & . & A & . & . & . & . & G & . & . & . & $\mathrm{T}$ & A & . \\
\hline Mysep5 & 1 & . & . & . & . & . & . & . & G & G & . & . & . & A & . & . & G & . & . & . & . & $\mathrm{T}$ & $\mathrm{T}$ & . & . & A & . \\
\hline Mysep9 & 1 & . & . & . & . & . & . & . & G & G & . & . & . & A & . & . & G & . & . & . & . & . & . & A & . & A & $\mathrm{T}$ \\
\hline Mysep10 & 92 & . & . & . & . & . & . & . & G & G & . & . & . & . & . & . & G & G & $\mathrm{T}$ & . & . & . & . & . & . & A & . \\
\hline Mysep11 & 3 & . & . & . & $\cdot$ & . & . & . & G & G & . & . & A & . & . & . & G & G & $\mathrm{T}$ & . & . & . & . & . & . & A & . \\
\hline Mysep12 & 11 & . & . & . & . & . & . & . & G & . & . & . & . & . & . & . & . & G & $\mathrm{T}$ & . & G & . & . & A & . & A & . \\
\hline Mysep13 & 27 & . & . & . & . & . & . & . & G & G & . & . & . & . & . & . & . & G & $\mathrm{T}$ & . & . & . & . & A & . & A & . \\
\hline Mysep14 & 1 & A & . & . & . & . & . & . & G & G & . & . & . & . & . & . & . & G & $\mathrm{T}$ & . & . & . & . & A & . & A & . \\
\hline
\end{tabular}

Note: Matrilines were defined by 26 variable sites within a 311 bp sequence observed among 154 individual bats. The dots indicate presence of the nucleotide shown for haplotype Mysep1.

assigned). Additionally, following onset of White-nose Syndrome at our sites in winter of 2013 (S. Carr, Kentucky Wildlife Resources Commission, personal communication), we were unable to reliably assign individuals to colonies or social groups in 2013 due to reduction in bat numbers and apparent collapse of maternity colonies locally, and therefore considered all individuals in that year nonassigned. In roost-removal treatments, secondary roosts were removed in colony $A$ and the primary roost was removed in colony D. No roosts were removed in colonies B, C, or E (Silvis et al. 2015b).

\section{Mitochondrial DNA variation}

Assembly and alignment of DNA sequences from a $311 \mathrm{bp}$ region of the mitochondrial D-loop of 154 unique northern long-eared bats (118 females and 36 males) revealed 18 haplotypes defined by 26 variable sites (Table 3). The respective haplotype sequences may be found on GenBank under accession numbers KT717660 (Mysep1) to KT717677 (Mysep18). The nucleotide diversity was $\pi=$ 0.00632 , the mean number of differences among individuals was $k=1.96$ nucleotides, $\theta_{\mathrm{w}}$ per sequence $=4.978$, and $\theta_{\mathrm{w}}$ per site $=$ 0.016 .

The mitochondrial haplotype network (Fig. 2) shows that the mitochondrial haplotypes of all northern long-eared bats were distributed rather evenly among the respective colonies, i.e., particular colonies were not dominated by any one haplotype or, hence, an associated matriline (Table 4; Supplementary Table S1ㄱ).

Mitochondrial DNA haplotype frequencies between colonies for females before and after roost removal are shown in Fig. 3. For all captured females (colonies A, B, C, D, E, and nonassigned), Mysep10 represented $71.2 \%$ of observations for $2011,62.9 \%$ for 2012 , and $75 \%$ for 2013. Although Mysep10 remained the most common haplotype among years, the frequencies of less-frequent haplotypes varied.

\section{Microsatellite DNA variation}

Among the six microsatellite loci screened across 167 individuals, variation at five microsatellite loci was consistently resolved (Table 1) with low inferred frequencies of null alleles. Variation at locus EfuF4 (Vonhof et al. 2002) was not consistently resolved and results for that locus were not considered in our analyses. All microsatellite DNA loci were polymorphic (Table 1), with $27.5 \pm$ 5.0 alleles per locus (mean $\pm \mathrm{SD}$ ). Expected heterozygosity $\left(H_{\mathrm{e}}\right)$ was $0.928 \pm 0.026$, observed heterozygosity $\left(H_{\mathrm{o}}\right)$ was $0.830 \pm 0.012$, and unbiased heterozygosity was $0.926 \pm 0.011$. The observed heterozygosity was somewhat lower than the expected heterozygosity, an outcome that may be explained by the presence of family structure within the population sampled, i.e., a departure from HardyWeinberg model assumptions.

Results of analysis of molecular variance (AMOVA; Table 5) showed that molecular genetic variance was predominantly within colonies (98.9\% of variance). Only a small proportion of genetic variance (1.1\%) was distributed between colonies, corresponding to an $\mathrm{F}_{\mathrm{ST}}=0.011$. Furthermore, use of a Bayesian assignment algorithm suggested that the data best conformed to one spatial cluster of multilocus genotypes in the study area, i.e., no differentiation among colonies was inferred. 
Fig. 2. Network showing the numbers of mutational steps among D-loop haplotypes observed in northern long-eared bats (Myotis septentrionalis) at Fort Knox, Kentucky, USA, 2011-2013. Circle sizes are proportional to the respective number of associated observations; haplotype distribution among colonies indicated by coloration. Smallest circles indicate haplotypes not observed that represent inferred mutational steps between observed haplotypes.

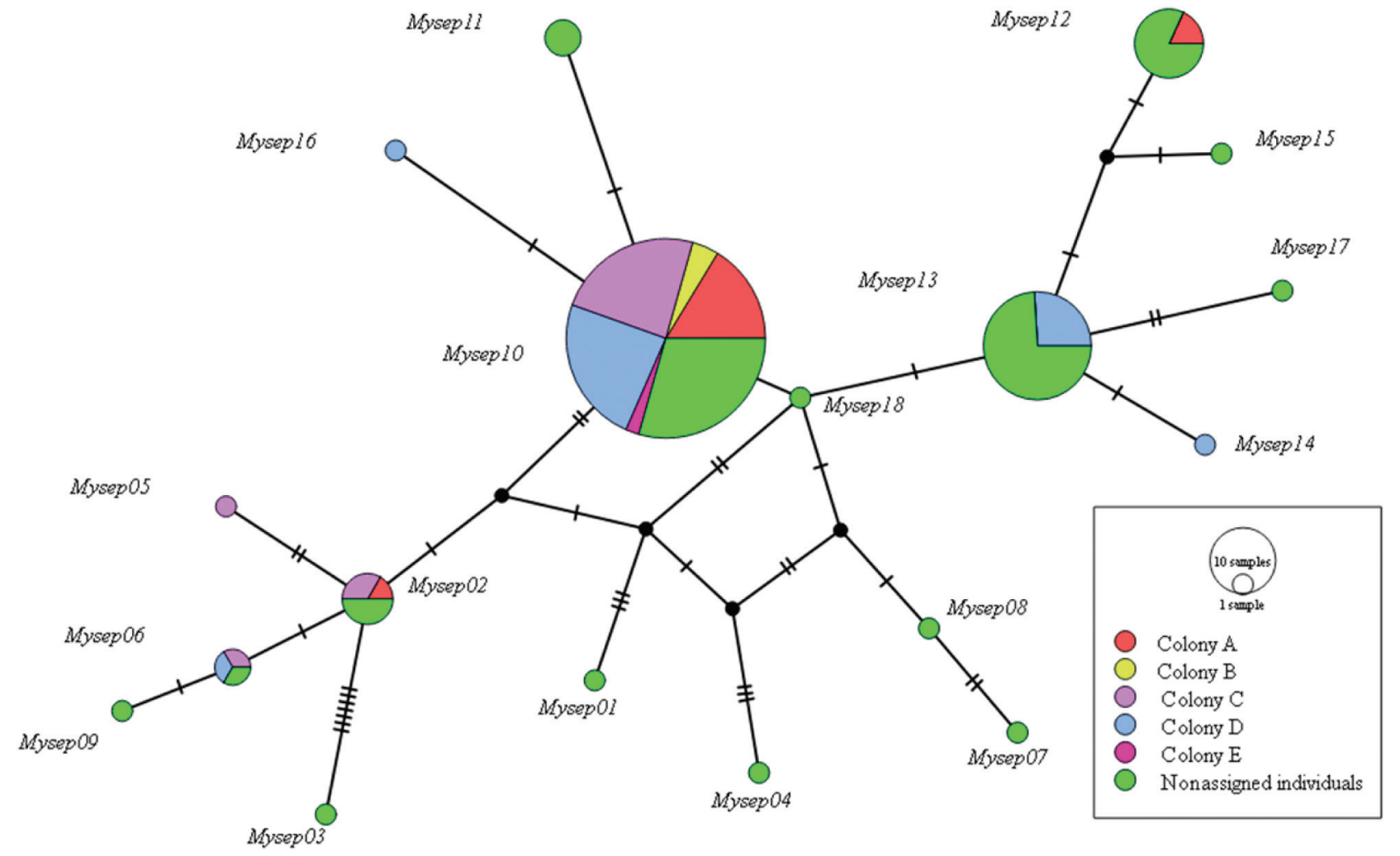

Among 340 tests, results of application of the parentage assignment algorithm to each year's data (Table 6) showed 60 putative parentage relationships, 56 of a focal individual and a mother only, and 2 of both putative parents (year-by-year analyses are shown in Supplementary Table S1). ${ }^{1}$ For 19 inferred pairs other than a female and juvenile of that year (Supplementary Table S1), ${ }^{1}$ the colony of mother and offspring matched over the duration of the study. Two were in untreated colony $\mathrm{C}$, eight were in primary roost-removal colony $\mathrm{D}$, and eight were in secondary roostremoval colony A. For 35 pairs, there was a mismatch among colonies, but the related individuals were found in adjacent roosting areas. For eight pairs, the individuals were not adjacent but were well within plausible flying distance $(10 \mathrm{~km})$ for the species. Two individuals were linked with putative fathers, both captured in colonies adjacent to the putative offspring. In one instance, our algorithm inferred four pairings of females where each could have been the parent of the other, which was an artifact of our inability to determine the ages of the respective individuals banded as adults. There were only five instances of inferred sons returning to the study area, two returning to the same colony as their mother and three to nearby colonies.

\section{Discussion}

\section{Genetic variation}

Our study differed from previous genetics studies of bats (Johnson et al. 2015) in terms of embodying more intensive sampling on a local scale, although Johnson et al. (2014) worked on a watershed to landscape spatial scale that was one hierarchal level above our work We observed a mean of 27.5 alleles per microsatellite locus, which is higher than in previous work in other regions (Arnold 2007; Johnson et al. 2014). Our expected and observed heterozygosities $(0.798$ and 0.692 , respectively) were higher than those reported by Arnold (2007) and Johnson et al. (2014). However, our results are not strictly comparable because those authors screened a different set of microsatellite marker loci. We observed a higher number of haplotypes than did Patriquin et al. (2013), who found only four haplotypes across 64 individuals. Mitochondrial haplotype diversity from our study $(h=0.618$ and $\pi=0.018$ ) was lower than that reported by Johnson et al. (2015). Overall, these differences with Johnson et al. (2015) may result from the smaller number of individuals and colonies that we screened, differences in markers used, or may represent variation among colonies; further research is needed to help elucidate these possibilities. Identification of a single spatial cluster of multilocus genotypes at our study sites is consistent with earlier studies of northern long-eared bats that have found little to no population genetic structuring across the range of the species (Johnson et al. 2014, 2015).

The haplotype network (Fig. 3) showed 18 haplotypes collectively involving 23 mutational steps. A network of such complexity - with so many observed and also inferred but unobserved haplotypes based on a sample of just 154 bats suggests that the assemblage of bats at this location represents but a sampling from a larger regional population with high genetic diversity. Johnson et al. (2014) found that northern long-eared bats within small areas of West Virginia, USA, and New York, USA, shared the same haplotypes.

\section{Colony genetic structure}

The frequency of mother-offspring relationships that we identified (17.6\% of all tests) was substantially lower than the $72 \%$ observed in another fission-fusing species, Bechstein's bat, by Kerth et al. (2002b). Importantly, the majority of mother-offspring pairs identified in our data consisted primarily of individuals in adjacent, rather than the same, colony. This spatial result may 
Table 4. Distribution of mitochondrial haplotypes among and within maternity colonies of northern long-eared bats (Myotis septentrionalis) at Fort Knox, Kentucky, USA, 2011-2013.

\begin{tabular}{|c|c|c|c|c|c|c|c|}
\hline \multirow[b]{2}{*}{ Colony } & \multirow[b]{2}{*}{ Haplotype } & \multicolumn{3}{|l|}{ Females } & \multicolumn{3}{|l|}{ Males } \\
\hline & & $\begin{array}{l}\text { Pre-roost } \\
\text { removal }\end{array}$ & $\begin{array}{l}\text { Post-roost } \\
\text { removal } \\
\text { (1 year later) }\end{array}$ & $\begin{array}{l}\text { Post-roost } \\
\text { removal } \\
\text { (2 years later) }\end{array}$ & $\begin{array}{l}\text { Pre-roost } \\
\text { removal }\end{array}$ & $\begin{array}{l}\text { Post-roost } \\
\text { removal } \\
\text { (1 year later) }\end{array}$ & $\begin{array}{l}\text { Post-roost } \\
\text { removal } \\
\text { (2 years later) }\end{array}$ \\
\hline \multirow[t]{4}{*}{$\bar{A}$} & Mysep2 & & 1 & & & & \\
\hline & Mysep10 & 2 & 11 & & & 1 & \\
\hline & Mysep11 & & & & & 1 & \\
\hline & Mysep12 & 1 & 1 & & & & \\
\hline B & Mysep10 & 2 & 2 & & & & \\
\hline \multirow[t]{4}{*}{$\bar{C}$} & Mysep2 & & 2 & & & & \\
\hline & Mysep5 & & 1 & & & & \\
\hline & Mysep6 & & 1 & & & & \\
\hline & Mysep10 & 12 & 9 & & & & \\
\hline$\overline{\mathrm{D}}$ & Mysep6 & 1 & & & & & \\
\hline $\bar{E}$ & Mysep10 & 2 & & & & & \\
\hline \multirow[t]{12}{*}{ Nonassigned individuals } & Mysep1 & & & & 1 & & \\
\hline & Mysep2 & & & & 1 & 2 & \\
\hline & Mysep3 & 1 & & & & & \\
\hline & Mysep4 & & & & 1 & & \\
\hline & Mysep6 & & 1 & & & & \\
\hline & Mysep7 & & & & & 1 & \\
\hline & Mysep8 & & & & & 1 & \\
\hline & Mysep9 & 1 & & & & & \\
\hline & Mysep10 & 10 & 3 & 6 & 5 & 4 & 2 \\
\hline & Mysep11 & & & & & 1 & 1 \\
\hline & Mysep12 & 2 & 1 & 1 & 3 & 2 & \\
\hline & Mysep 13 & 1 & 2 & 1 & 1 & 2 & 3 \\
\hline
\end{tabular}

have depended on when we caught bats; earlier in the season, the young may have been in their natal colony, while later they had dispersed. Although observed parentages may have been low because we did not capture all individuals in colonies, exit counts suggest that we captured between $60 \%$ and $100 \%$ of all individuals within maternity colonies. Furthermore, we found that genetic variance was predominantly within rather than among colonies, with mitochondrial DNA haplotypes distributed more or less evenly among colonies. Based on the combined evidence of even haplotype distribution, low levels of relatedness, low parentage rate, mother-offspring relationships among colonies, and genetic variance partitioning, we conclude that there is little evidence that colonies were closed groups of sisters, their offspring, or close maternal relatives on an annual basis. The number of inferred parentages between adjacent colonies suggests that weaned pups may disperse to adjacent areas and that adult bats, especially females, may return to the approximate vicinity of their natal area. The presence of nonoverlapping colony roosting areas (Silvis et al. 2014, 2015b) and low frequency of individual movements among colonies support the view that colonies still may be relatively closed seasonally once established. The number of parentages that we inferred among colonies, however, suggests that after the maternity season, or when bats disperse from caves, social groups may be relatively flexible and open, with individuals moving among groups close to their natal area.

Our findings regarding relatedness of colony members contrast with those of Patriquin et al. (2013), who found that northern long-eared bats that roost together are related and suggested that kin selection may partially explain maternity colony social dynamics. We note that Patriquin et al. (2013) focused more closely on preferential associations among individuals within maternity colonies, whereas our study focused on associations mostly at the colony level. It is possible that different environmental constraints arising from substantially different climatic and habitat conditions between our study site and that of Patriquin et al. (2013) at the species' northern distribution limit in Nova Scotia, Canada, resulted in different patterns of behavior. Indeed, behavioral differences in roost switching and selection have been noted between these two locations (Patriquin et al. 2016). Given that juvenile bat development is positively associated with temperature (Zahn 1999; Lourenço and Palmeirim 2004), warmer conditions in Kentucky may have lessened necessity for social thermoregulation and therefore (kin) selection pressure at our study site relative to that studied by Patriquin et al. (2013). Climatic pressure on sociality and roost-sharing is known from other bat species (Trune and Slobodchikoff 1976; Willis and Brigham 2007; Angell et al. 2013). Alternatively, relatively few roosting opportunities due to forest community and (or) forest stand condition may limit dispersal potential, and thus, result in more closely related colonies, whereas abundant roosting opportunities (such as at our study area, an older forest in the understory re-initiation phase) may permit greater dispersal across the landscape, thereby lessening relatedness within colonies. Relationships between habitat quality and dispersal have been noted in a number of species 
Fig. 3. Frequencies of mitochondrial DNA haplotypes among northern long-eared bats (Myotis septentrionalis) at Fort Knox, Kentucky, USA, before and after primary or secondary roost removal.

\section{1}

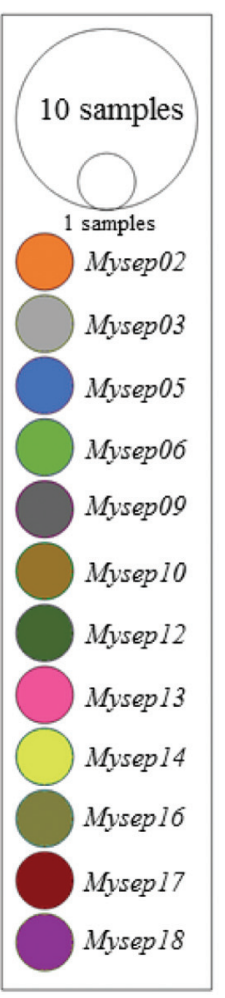

Colony A

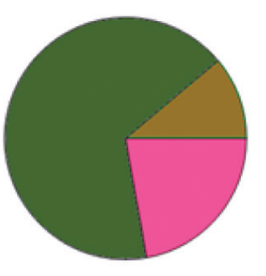

Colony C

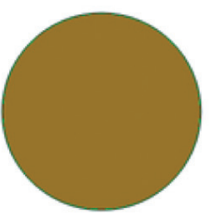

Colony E
Colony B

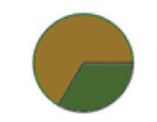

Colony D

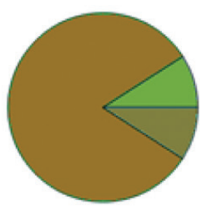

Nonassigned individuals

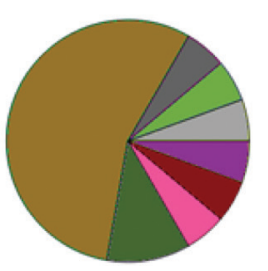

$\underline{2012}$

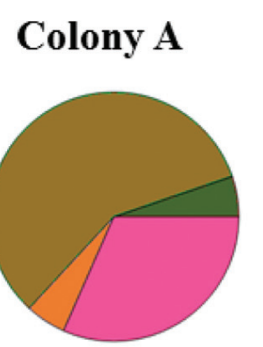

Colony C

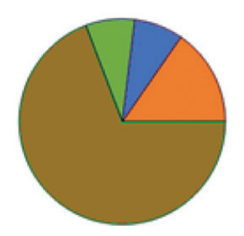

No recorded individuals for Colony E
Colony B

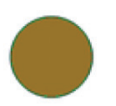

Colony D

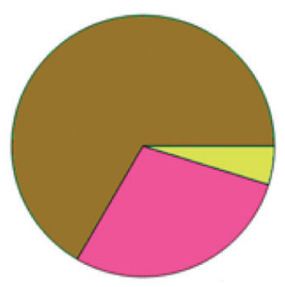

Nonassigned individuals

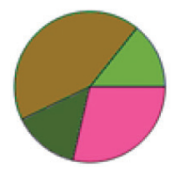

across a variety of taxa (Stow et al. 2001; Bowler and Benton 2005; Clutton-Brock and Lukas 2012), but are unknown for temperate bats.

We conclude that female bats do join social networks, then, not to increase their inclusive fitness via kin selection, but rather for other reasons. Cooperation among colony members may be invoked to explain this social system, particularly if roosts serve as center for sharing information (Wilkinson 1992; Bijleveld et al. 2010). For example, colony members frequently groom each other and exchange information about novel roosts (Kerth 1998; Kerth et al. 2001a, 2006; Kerth and Reckardt 2003; Metheny et al. 2008a), or if pregnant or lactating, then colony members may present a form of cooperative warming (Kerth and Konig 1999; Kerth et al. $2001 b$ ). Thus, formation of social networks also may serve different purposes under different ecological conditions, mitigate different limiting ecological factors, and the rules of association may be a balance of group decision-making and communal interest (Kerth et al. 2006; Sueur et al. 2011; Fleischmann et al. 2013).

\section{Effects of roost removal}

Assessment of movement patterns and roost selection and roost-switching data for radio-tagged female bats showed that colonies followed in this study persisted despite roost-removal treatments (Silvis et al. 2015b). However, near complete colony membership turnover was observed. Because no long-term monitoring has been conducted on northern long-eared bat maternity colonies, reasons for colony turnover are unclear. Nonetheless, it is possible that roost removal disturbed colonies and resulted in colony abandonment by individuals observed in the first year of our study. Referring back to the hypotheses tested in this study, given that individuals within and from neighboring colonies are maternally related, albeit at low levels, several possible outcomes in genetic structure may be expected if roosting areas were aban- doned due to roost loss: (i) if individual bats from a broad area opportunistically occupied newly abandoned areas, then relatedness within colonies and between neighboring colonies would be lower than observed pre-removal; (ii) if individual bats from neighboring colonies opportunistically occupied newly abandoned areas, then relatedness values may not change; (iii) if an existing colony in suboptimal habitat occupied newly abandoned areas, then within-colony relatedness would be similar to that of other colonies, but relatedness to neighboring colonies would be low. Our original working hypothesis was that with a roost removal, one of two things would happen: (1) bats that came back to find reduced habitat availability would partition themselves into more completely related matrilines, i.e., grandmothers, mothers, and daughters, and there would be no or proportionally fewer cousins; or (2) with sudden habitat disruption, $\mathrm{H}_{1}$, that is individuals from a broad area would opportunistically occupy newly abandoned areas, would become operative. Whereas $\mathrm{H}_{3}$, that complete colonies in suboptimal areas would occupy treated areas, was of interest, in reality we could not effectively test that because of the outbreak of White-nose Syndrome.

It seems unlikely that turnover in colony membership was related to roost-removal treatments, as we observed similar changes in turnover in the control colony $(\mathrm{C})$ for which no roosts were removed. Likewise, we found that genetic structuring of maternity colonies in terms of spatial distribution and partition of genetic variation was largely consistent before and after roost removal across all colonies. Our observed genetic structures within and among treatment colonies argue against scenarios 1 and 3 above, and absence of movement of tagged bats from the first year into new colony areas argues against scenario 2 . Local area, but not specific colony membership fidelity, could explain the observed colony membership turnover and patterns of maternalpup relatedness among colonies, as well as low relatedness levels 
Table 5. Analysis of molecular variance for microsatellite allele frequencies in a northern long-eared bat (Myotis septentrionalis) population at Fort Knox, Kentucky, USA, 2011-2012.

\begin{tabular}{|c|c|c|c|c|}
\hline \multicolumn{5}{|l|}{ Colony A* } \\
\hline Source of variation & $\mathrm{df}$ & Sum of squares & Variance components & Percentage variation \\
\hline Among populations & 1 & 2.244 & -0.02733 & -0.98 \\
\hline Within populations & 54 & 152.167 & 2.81790 & 100.98 \\
\hline Total & 55 & 154.411 & 2.79057 & \\
\hline \multicolumn{5}{|l|}{$\overline{\text { Colony B }}^{\dagger}$} \\
\hline Source of variation & $\mathrm{df}$ & Sum of squares & Variance components & Percentage variation \\
\hline Among populations & 1 & 2.875 & 0.06250 & 2.33 \\
\hline Within populations & 6 & 15.750 & 2.62500 & 97.67 \\
\hline Total & 7 & 18.625 & 2.68750 & \\
\hline \multicolumn{5}{|l|}{$\overline{\text { Colony } \mathrm{C}^{\ddagger}}$} \\
\hline Source of variation & $\mathrm{df}$ & Sum of squares & Variance components & Percentage variation \\
\hline Among populations & 1 & 3.765 & 0.03572 & 1.29 \\
\hline Within populations & 56 & 153.476 & 2.74064 & 98.71 \\
\hline Total & 57 & 157.241 & 2.77636 & \\
\hline \multicolumn{5}{|l|}{ Colony D\$ } \\
\hline Source of variation & $\mathrm{df}$ & Sum of squares & Variance components & Percentage variation \\
\hline Among populations & 1 & 3.397 & 0.01951 & 0.70 \\
\hline Within populations & 70 & 192.450 & 2.74928 & 99.30 \\
\hline Total & 71 & 195.847 & 2.76879 & \\
\hline
\end{tabular}

Note: Significance testing involved 1023 permutations with significant results set in boldface type.

*Overall fixation index $\left(F_{\mathrm{ST}}\right)=-0.00979$; variation among populations: $F_{\mathrm{ST}}$ (random values $>$ observed values) $=0.98436$; $P($ random value $=$ observed value $)=0.00196 ; P=0.98631 \pm 0.00309$.

†Overall $F_{\mathrm{ST}}=0.02326$; variation among populations: $F_{\mathrm{ST}}$ (random values $>$ observed values) $=0.33138 ; P($ random value $=$ observed value) $=0.33236 ; P=0.66373 \pm 0.01586$.

‡Overall $F_{\mathrm{ST}}=0.01287$; variation among populations: $F_{\mathrm{ST}}$ (random values $>$ observed values $)=0.11339 ; P($ random value $=$ observed value $)=0.00000 ; P=0.11339 \pm 0.01167$.

§Overall $F_{\mathrm{ST}}=0.00705$; variation among populations: $F_{\mathrm{ST}}$ (random values $>$ observed values $)=0.29912 ; P($ random value $=$ observed value $)=0.00000 ; P=0.29912 \pm 0.01263$

Table 6. Summary of inferred parentage relationships among northern long-eared bats (Myotis septentrionalis) in maternity colonies at Fort Knox, Kentucky, USA, 2011-2013.

\begin{tabular}{lllllll}
\hline \multicolumn{7}{l}{ Candidate mother } \\
\cline { 2 - 7 } Candidate offspring & Colony A & Colony B & Colony C & Colony D & Colony E & Nonassigned individuals \\
\hline Colony A & 4 & 1 & & & \\
Colony B & 0 & 0 & 5 & 2 & & \\
Colony C & 0 & 1 & 2 & 5 & & \\
Colony D & 0 & 0 & 0 & 0 & 0 & \\
Colony E & 5 & 3 & 4 & 5 & 0 & \\
Nonassigned individuals & Candidate father & & & & \\
\hline & Colony A & Colony B & Colony C & Colony D & Colony E & Nonassigned individuals \\
Candidate offspring & 0 & & & & & \\
\hline Colony A & 0 & 0 & & & & \\
Colony B & 0 & 0 & 0 & & & \\
Colony C & 0 & 0 & 0 & 0 & 0 & \\
Colony D & 0 & 0 & 0 & 0 & 0 & \\
Colony E & 1 & 0 & 0 & 0 & & \\
Nonassigned individuals & 1 & & & & & \\
\hline
\end{tabular}

within colonies and low recapture rates due to high individual turnover. Persistence of social structure despite substantial changes in colony structure has been noted in Bechstein's bat (Baigger et al. 2013).

Although differences in genetic structure in the secondary roost-removal colony could indicate a treatment effect, the secondary roost-removal colony (A) also had the lowest level of relatedness pre-treatment and differed substantially from both the control (C) and the primary roost-removal (D) colonies pretreatment for colonies monitored in this study. Instead of poten- tially splitting, as suggested by Silvis et al. (2015b), it is possible that the secondary roost-removal colony A was stabilizing or newly forming rather than fragmenting. This colony exhibited both behavioral and genetic differences from our other colonies, i.e., differences in patterns of movement by individuals among roosts and association patterns post-roost removal, and no apparent relatedness pre-roost removal. However, the shift in relatedness toward the levels observed in our other treatment colonies, combined with consistent space use and roost selection, would suggest robustness rather than susceptibility to roost loss. 


\section{Life-history insights}

Although we inferred many cases of parentage involving putative mothers, we inferred the presence of only two fathers on the study site. These inferences are consistent with two fathers by chance dispersing to the maternity area from a nearby hibernaculum that the bats used for swarming and the short distance dispersal from hibernacula. Presence of offspring within colonies or close proximity to natal colonies is known in other bats. For example, in the mouse-eared bat (Myotis myotis (Borkhauser, 1797)), $16 \%$ of marked females appeared at least once in non-natal colonies and about 6\% switched colonies permanently (Zahn 1998). Female brown long-eared bat (Plecotus auritus (Linnaeus, 1758)) (Entwistle et al. 2000) and greater horseshoe bat (Rossiter et al. 2000) occasionally switched colonies. Even with occasional colony switching, female colony fidelity has been observed in the Australian false vampire bat (Macroderma gigas (Dobson, 1880)) (Wilmer et al. 1994), mouse-eared bat (Petri et al. 1997; Castella et al. 2001), brown long-eared bat (Burland et al. 1999), and Bechstein's bat (Kerth et al. 2002b). Presence of related females across years, as observed through inferred parentages, supports recapture data that female northern long-eared bats exhibit some degree of site fidelity (Perry 2011).

Similar to the sympatric and endangered Indiana bat (Myotis sodalis Miller and G.M. Allen, 1928), some female northern longeared bats probably return to their natal roost areas during the summer maternity period (Kurta and Murray 2002; Kurta et al. 2002). However, our low recapture rate between years, despite high overall capture rates of bats within colonies, and low relatedness among females, suggests that philopatry to a specific colony may be low. High levels of philopatry should result in higher than expected relatedness among individuals within a summering site if each site is inhabited by only a few maternal groups. Philopatry to summering sites in the year after birth, but not subsequently, may allow individuals to gain or maximize knowledge of resources including food and suitable roosts, which could increase survival (Morrison 1980; Lewis 1995), while also reducing subsequent competition with offspring. Alternatively, bats may be responding to the ephemerality of the habitat and have difficulty reforming colonies, or roosts may be abundant and thereby pressures to reform specific colonies are limited. Additionally, although roosts and roost areas were used among years by northern long-eared bats, our results suggest high individual turnover of bats at our study site.

Our case study of movement and genetics of northern longeared bats showed that members of social groups are not related and that multiple maternal groups of largely unrelated individuals share a single summering site. Hence, the fitness benefits of sociality are not favored by kin selection and must be indirect. Although our data on movement and genetics do not support inference of the mechanisms supporting colony formation, because the colonies include mothers and unweaned offspring and last only through the nursing period, it is clear that benefits must increase the survival of young. Characterization of the benefits of social groups could perhaps best be achieved by monitoring of behavior using in-colony cameras. Similar evidence of philopatric behavior towards summering colonies coupled with low values of relatedness has been observed in other bats, including the brown long-eared bat (Burland et al. 2001) and Bechstein's bat (Kerth et al. 2002b). Johnson et al. (2015) suggested explanations for conflicting behavioral and genetic signatures of philopatry. First, the origin of mitochondrial DNA haplotypes can pre-date the separation or origin of maternity colonies, resulting in the same haplotypes being spread across multiple colonies. Secondly, even a small number of dispersing individuals can dilute the genetic signature of philopatry across sites. Mean relatedness therefore may be a poor estimator for the potential of kin selection in bat colonies and may be misleading when attempting to understand the social structure of animals living in groups where many members breed (Kerth et al. 2002b).

\section{Conclusions}

Our results highlight genetic structure within and among neighboring maternity colonies of northern long-eared bats and provide some evidence that kin selection is not a primary proximate factor associated with colony formation or dynamics, though kin selection may exist under some conditions (Patriquin et al. 2013). Low levels of relatedness among neighboring colonies suggest that colony formation is not necessarily tied to budding of matrilines from existing colonies. Our results add clarity to the apparent fission of the secondary roost-removal treatment colony (B) observed by Silvis et al. (2015b). Whereas the primary roostremoval colony (A) and the control colony (C) consisted primarily of a single haplotype, the secondary roost-removal colony was split between two relatively frequent haplotypes. Although the two haplotypes in the secondary roost-removal colony also were the most common haplotypes in all other colonies, it is possible that this colony was undergoing a fission event due to changes in matriline composition rather than as a result of treatment effects. Alternately, we may have observed a colony formation event in the first year of our study, during which unrelated individuals coalesced into a group. The subsequent increase in relatedness in the second year of our study could reflect mother-offspring relations or recruitment of other relatives. Finally, our documentation of relatedness within and among northern long-eared bat maternity colonies provides benchmark data that may be used to assess the consequences of White-nose Syndrome at the population and social group levels.

\section{Acknowledgements}

This research was supported by the U.S. Army Environmental Quality and Installation Basic Research 6.1 program. The Kentucky Department of Fish and Wildlife Resources graciously provided field housing for this project. Additional funding was provided by the Virginia Agricultural Experiment Station and the U.S. Department of Agriculture National Institute of Food and Agriculture. The manuscript was improved by attending to the comments of the anonymous reviewers. The use of any trade, product, or firm names does not imply endorsement by the U.S. Government.

\section{References}

Angell, R.L., Butlin, R.K., and Altringham, J.D. 2013. Sexual segregation and flexible mating patterns in temperate bats. PLoS ONE, 8: e54194. doi:10.1371/ journal.pone.0054194. PMID:23365652.

Anthony, E.L.P. 1988. Age determination in bats. In Ecological and behavioral methods for the study of bats. Edited by T.H. Kunz. Smithsonian Institution Press, Washington, D.C. pp. 47-58.

Arms, E.L.P., Mitchell, M.J., Watts, F.C., and Wilson, B.L. 1979. Soil survey of Hardin and Larue Counties, Kentucky. USDA Soil Conservation Service. Available from https://www.nrcs.usda.gov/Internet/FSE_MANUSCRIPTS/kentucky/ KY621/0/Hardin.pdf [accessed 2 January 2018].

Arnold, B.D. 2007. Population structure and sex-biased dispersal in the forest dwelling vespertilionid bat, Myotis septentrionalis. Am. Midl. Nat. 157: 374-384. doi:10.1674/0003-0031(2007)157[374:PSASDI]2.0.CO;2.

Aureli, F., Schaffner, C.M., Boesch, C., Bearder, S.K., Call, J., Chapman, C.A., Connor, R., Fiore, A.D., Dunbar, R.I., Henzi, S.P., and Holekamp, K. 2008. Fission-fusion dynamics: new research frameworks. Curr. Anthropol. 49: 627-654. doi:10.1086/586708.

Baigger, A., Perony, N., Reuter, M., Leinert, V., Melber, M., Grünberger, S., Fleischmann, D., and Kerth, G. 2013. Bechstein's bats maintain individual social links despite a complete reorganisation of their colony structure. Naturwissenschaften, 100: 895-898. doi:10.1007/s00114-013-1090-x. PMID: 23949307.

Barbour, R.W., and Davis, W.H. 1969. Bats of America. University Press of Kentucky, Lexington.

Bijleveld, A.I., Egas, M., Van Gils, J.A., and Piersma, T. 2010. Beyond the information centre hypothesis: communal roosting for information on food, predators, travel companions and mates? Oikos, 119: 277-285. doi:10.1111/j.1600-0706. 2009.17892.x.

Bowler, D.E., and Benton, T.G. 2005. Causes and consequences of animal disper- 
sal strategies: relating individual behaviour to spatial dynamics. Biol. Rev. Camb. Philos. Soc. 80: 205-225. doi:10.1017/S1464793104006645. PMID: 15921049.

Bradbury, J.W. 1977. Social organisation and communication. In Biology of bats. Edited by W.A. Wimsatt. Academic Press, New York. pp. 1-72.

Brookfield, J.F.Y.1996. A simple new method for estimating null allele frequency from heterozygote deficiency. Mol. Ecol. 5: 453-455. doi:10.1111/j.1365-294X. 1996.tb00336.x. PMID:8688964.

Burland, T.M., Barratt, E.M., Beaumont, M.A., and Racey, P.A. 1999. Population genetic structure and gene flow in a gleaning bat, Plecotus auritus. Proc. R. Soc. B Biol. Sci. 266: 975-980. doi:10.1098/rspb.1999.0732.

Burland, T.M., Barratt, E.M., Nichols, R.A., and Racey, P.A. 2001. Mating patterns, relatedness and the basis of natal philopatry in the brown long-eared bat, Plecotus auritus. Mol. Ecol. 10: 1309-1321. doi:10.1046/j.1365-294X.2001.01273.x. PMID:11380886.

Caceres, M.C., and Barclay, R.M.R. 2000. Myotis septentrionalis. Mamm. Species, 634: 1-4. doi:10.1644/1545-1410(2000)634<0001:MS>2.0.CO;2.

Castella, V., and Ruedi, M. 2000. Characterization of highly variable microsatellite loci in the bat Myotis myotis (Chiroptera: Vespertilionidae). Mol. Ecol. 9: 1000-1002. doi:10.1046/j.1365-294x.2000.00939-6.x. PMID:10886666.

Castella, V., Ruedi, M., and Excoffier, L. 2001. Contrasted patterns of mitochondrial and nuclear structure among nursery colonies of the bat Myotis myotis. J. Evol. Biol. 14: 708-720. doi:10.1046/j.1420-9101.2001.00331.x.

Chaverri, G. 2010. Comparative social network analysis in a leaf-roosting bat. Behav. Ecol. Sociobiol. 64: 1619-1630. doi:10.1007/s00265-010-0975-3.

Clutton-Brock, T.H., and Lukas, D. 2012. The evolution of social philopatry and dispersal in female mammals. Mol. Ecol. 21: 472-492. doi:10.1111/j.1365-294X. 2011.05232.x. PMID:21883582.

Entwistle, A.C., Racey, P.A., and Speakman, J.R. 2000. Social and population structure of a gleaning bat, Plecotus auritus. J. Zool. (Lond.), 252: 11-17. doi:10. 1111/j.1469-7998.2000.tb00815.x.

Evanno, G., Regnaut, S., and Goudet, J. 2005. Detecting the number of clusters of individuals using the software STRUCTURE: a simulation study. Mol. Ecol. 14: 2611-2620. doi:10.1111/j.1365-294X.2005.02553.x. PMID:15969739.

Excoffier, L., and Lischer, H.E.L. 2010. Arlequin suite ver 3.5: a new series of programs to perform population genetics analyses under Linux and Windows. Mol. Ecol. Resour. 10: 564-567. doi:10.1111/j.1755-0998.2010.02847.x. PMID:21565059.

Excoffier, L., Smouse, P.E., and Quattro, J.M. 1992. Analysis of molecular variance inferred from metric distances among DNA haplotypes: application to human mitochondrial DNA restriction data. Genetics, 131: 479-491. PMID: 1644282.

Fleischmann, D., Baumgartner, I.O., Erasmy, M., Gries, N., Melber, M., Leinert, V., Parchem, M., Reuter, M., Schaer, P., Stauffer, S., and Wagner, I. 2013. Female Bechstein's bats adjust their group decisions about communal roosts to the level of conflict of interests. Curr. Biol. 23: 1658-1662. doi:10. 1016/j.cub.2013.06.059. PMID:23954425.

Ford, W.M., Silvis, A., Johnson, J.B., Edwards, J.W., and Karp, M. 2016. Northern long-eared bat day-roosting and prescribed fire in the central Appalachians. Fire Ecol. 12: 13-27. doi:10.4996/fireecology.1202013.

Frank, S.A. 2013. Natural selection. VII. History and interpretation of kin selection theory. J. Evol. Biol. 26: 1151-1184. doi:10.1111/jeb.12131. PMID:23662923.

Fumagalli, L., Taberlet, P., Favre, L., and Hausser, J. 1996. Origin and evolution of homologous repeated sequences in the mitochondrial DNA control region of shrews. Mol. Biol. Evol. 13: 31-46. doi:10.1093/oxfordjournals.molbev. a025568. PMID:8583904.

Garroway, C.J., and Broders, H.G. 2007. Nonrandom association patterns at northern long-eared bat maternity roosts. Can. J. Zool. 85(9): 956-964. doi: 10.1139/Z07-079.

Garroway, C.J., and Broders, H.G. 2008. Day roost characteristics of northern long-eared bats (Myotis septentrionalis) in relation to female reproductive status. Ecoscience, 15: 89-93. doi:10.2980/1195-6860(2008)15[89:DRCONL]2.0. $\mathrm{CO} ; 2$

Jennions, M.D., and Macdonald, D.W. 1994. Cooperative breeding in mammals. Trends Ecol. Evol. 9: 89-93. doi:10.1016/0169-5347(94)90202-X. PMID: 21236784

Johnson, J.B., Edwards, J.W., Ford, W.M., and Gates, J.E. 2009. Roost tree selection by northern myotis (Myotis septentrionalis) maternity colonies following prescribed fire in a central Appalachian Mountains hardwood forest. For. Ecol. Manage. 258: 233-242. doi:10.1016/j.foreco.2009.04.008.

Johnson, J.B., Ford, W.M., and Edwards, J.W. 2012a. Roost networks of northern myotis (Myotis septentrionalis) in a managed landscape. For. Ecol. Manage. 266: 223-231. doi:10.1016/j.foreco.2011.11.032.

Johnson, J.B., Roberts, J.H., King, T.L., Edwards, J.W., Ford, W.M., and Ray, D.A. 2014. Genetic structuring of northern myotis (Myotis septentrionalis) at multiple spatial scales. Acta Theriol. 59(2): 223-231. doi:10.1007/s13364-013-0163-8.

Johnson, J.S., Kropczynski, J.N., Lacki, M.J., and Langlois, G.D. 2012b. Social networks of Rafinesque's big-eared bats (Corynorhinus rafinesquii) in bottomland hardwood forests. J. Mammal. 93: 1545-1558. doi:10.1644/12-MAMM-A-097.1.

Johnson, L.N.L., McLeod, B.A., Burns, L.E., Arseneault, K., Frasier, T.R., and Broders, H.G. 2015. Population genetic structure within and among seasonal site types in the little brown bat (Myotis lucifugus) and the northern long-eared bat (M. septentrionalis). PLoS ONE, 10: e0126309. doi:10.1371/journal.pone. 0126309. PMID:25942425.

Kalinowski, S.T., Taper, M.L., and Marshall, T.C. 2007. Revising how the computer program CERVUS accommodates genotyping error increases success in paternity assignment. Mol. Ecol. 16: 1099-1106. doi:10.1111/j.1365-294X.2007. 03089.x. PMID:17305863.

Kerth, G. 1998. Sozialverhalten und Genetische Populationsstruktur bei der Bechsteinfledermaus (Myotis bechsteinii). Wissenschaft und Technik, Berlin, Germany.

Kerth, G. 2008. Causes and consequences of sociality in bats. BioScience, 58: 737-746. doi:10.1641/B580810.

Kerth, G., and Konig, B. 1999. Fission, fusion and nonrandom associations in female Bechstein's bats (Myotis bechsteinii). Behaviour, 136: 1187-1202. doi:10. $1163 / 156853999501711$

Kerth, G., and Reckardt, K. 2003. Information transfer about roosts in female Bechstein's bats: an experimental field study. Proc. R. Soc. B Biol. Sci. 270: 511-515. doi:10.1098/rspb.2002.2267.

Kerth, G., Wagner, M., and König, B. 2001a. Roosting together, foraging apart: information transfer about food is unlikely to explain sociality in female Bechstein's bats (Myotis bechsteinii). Behav. Ecol. Sociobiol. 50: 283-291. doi:10. 1007/s002650100352.

Kerth, G., Weissmann, K., and König, B. 2001b. Day roost selection in female Bechstein's bats (Myotis bechsteinii): a field experiment to determine the influence of roost temperature. Oecologia, 126: 1-9. doi:10.1007/s004420000489. PMID:28547427.

Kerth, G., Mayer, F., and Petit, E. 2002a. Extreme sex-biased dispersal in the communally breeding, nonmigratory Bechstein's bat (Myotis bechsteinii). Mol. Ecol. 11: 1491-1498. doi:10.1046/j.1365-294X.2002.01528.x. PMID:12144668.

Kerth, G., Safi, K., and König, B. 2002b. Mean colony relatedness is a poor predictor of colony structure and female philopatry in the communally breeding Bechstein's bat (Myotis bechsteinii). Behav. Ecol. Sociobiol. 52: 203-210. doi:10.1007/s00265-002-0499-6.

Kerth, G., Ebert, C., and Schmidtke, C. 2006. Group decision making in fissionfusion societies: evidence from two-field experiments in Bechstein's bats. Proc. R. Soc. B Biol. Sci. 273: 2785-2790. doi:10.1098/rspb.2006.3647.

Kerth, G., Perony, N., and Schweitzer, F. 2011. Bats are able to maintain long-term social relationships despite the high fission-fusion dynamics of their groups. Proc. R. Soc. B Biol. Sci. 278: 2761-2767. doi:10.1098/rspb.2010.2718.

Kummer, H. 1971. Primate societies: group techniques of ecological adaptation. Aldine, Chicago, Ill.

Kurta, A., and Murray, S.W. 2002. Philopatry and migration of banded Indiana bats (Myotis sodalis) and effects of radio transmitters. J. Mammal. 83: 585-589. doi:10.1644/1545-1542(2002)083<0585:PAMOBI>2.0.CO;2.

Kurta, A., Murray, S.W., and Miller, D.H. 2002. Roost selection and movements across the summer landscape. In The Indiana bat: biology and management of an endangered species. Edited by A. Kurta and J. Kennedy. Bat Conservation International, Austin, Tex. pp. 118-129.

Leigh, J.W., and Bryant, D. 2015. POPART: full-feature software for haplotype network construction. Methods Ecol. Evol. 6: 1110-1116. doi:10.1111/2041-210X. 12410.

Lewis, S.E. 1995. Roost fidelity of bats: a review. J. Mammal. 76: 481-496. doi:10. 2307/1382357.

Lourenco, S.I., and Palmeirim, J.M. 2004. Influence of temperature in roost selection by Pipistrellus pygmaeus (Chiroptera): relevance for the design of bat boxes. Biol. Conserv. 119: 237-243. doi:10.1016/j.biocon.2003.11.006.

Marshall, J.A.R. 2011. Group selection and kin selection: formally equivalent approaches. Trends Ecol. Evol. 26: 325-332. doi:10.1016/j.tree.2011.04.008. PMID:21620513.

Metheny, J.D., Kalcounis-Rueppell, M.C., Bondo, K.J., and Brigham, R.M. 2008a. A genetic analysis of group movement in an isolated population of treeroosting bats. Proc. R. Soc. B Biol. Sci. 275: 2265-2272. doi:10.1098/rspb.2008. 0532 .

Metheny, J.D., Kalcounis-Rueppell, M.C., Willis, C.K.R., Kolar, K., and Brigham, R.M. 2008b. Genetic relationships between roost-mates in a fissionfusion society of tree-roosting big brown bats (Eptesicus fuscus). Behav. Ecol. Sociobiol. 62: 1043-1051. doi:10.1007/s00265-007-0531-y.

Morrison, D.W. 1980. Foraging and day-roosting dynamics of canopy fruit bats in Panama. J. Mammal. 61: 20-29. doi:10.2307/1379953.

Owen, S.F., Menzel, M.A., Ford, W.M., Edwards, J.W., Chapman, B.R., Miller, K.V., and Wood, P.B. 2002. Roost tree selection by maternal colonies of northern long-eared myotis in an intensively managed forest. Gen. Tech. Rep. NE-292, U.S. Department of Agriculture Forest Service Northeastern Research Station, Newton Square, Pa.

Patriquin, K.J., Leonard, M.L., Broders, H.G., and Garroway, C.J. 2010. Do social networks of female northern long-eared bats vary with reproductive period and age? Behav. Ecol. Sociobiol. 64: 899-913. doi:10.1007/s00265-010-0905-4.

Patriquin, K.J., Palstra, F.M.L., Leonard, C.J., and Broders, H.G. 2013. Female northern myotis (Myotis septentrionalis) that roost together are related. Behav. Ecol. 24: 949-954. doi:10.1093/beheco/art012.

Patriquin, K.J., Leonard, M.L., Broders, H.G., Ford, W.M., Britzke, E.R., and Silvis, A. 2016. Weather as a proximate explanation for fission-fusion dynamics in female northern long-eared bats. Anim. Behav. 122: 47-57. doi:10.1016/ j.anbehav.2016.09.022. 
Perry, R.W. 2011. Fidelity of bats to forest sites revealed from mist-netting recaptures. J. Fish Wildl. Manage. 2: 112-116. doi:10.3996/082010-JFWM-030.

Perry, R.W., and Thill, R.E. 2007. Roost selection by male and female northern long-eared bats in a pine-dominated landscape. For. Ecol. Manage. 247: 220226. doi:10.1016/j.foreco.2007.04.041.

Petri, B., Pääbo, S., Von Haeseler, A., and Tautz, D. 1997. Paternity assessment and population subdivision in a natural population of the larger mouseeared bat Myotis myotis. Mol. Ecol. 6: 235-242. doi:10.1046/j.1365-294X.1997. 00176.x. PMID:9076978.

Popa-Lisseanu, A.G., Bontadina, F., Mora, O., and Ibáñez, C. 2008. Highly structured fission-fusion societies in an aerial-hawking, carnivorous bat. Anim. Behav. 75: 471-482. doi:10.1016/j.anbehav.2007.05.011.

Pritchard, J.K., Stephens, M., and Donnelly, P. 2000. Inference of population structure using multilocus genotype data. Genetics, 155: 945-959. PMID: 10835412.

Queller, D.C. 2011. Expanded social fitness and Hamilton's rule for kin, kith, and kind. Proc. Natl. Acad. Sci. U.S.A. 108: 10792-10799. doi:10.1073/pnas. 1100298108. PMID:21690389.

Rhodes, M. 2007. Roost fidelity and fission-fusion dynamics of white-striped free-tailed bats (Tadarida australis). J. Mammal. 88: 1252-1260. doi:10.1644/06MAMM-A-374R1.1.

Rivers, N.M., Butlin, R.K., and Altringham, J.D. 2005. Genetic population structure of Natterer's bats explained by mating at swarming sites and philopatry. Mol. Ecol. 14: 4299-4312. doi:10.1111/j.1365-294X.2005.02748.x. PMID:16313594.

Rossiter, S.J., Jones, G., Ransome, R.D., and Barratt, E.M. 2000. Genetic variation and population structure in the endangered greater horseshoe bat Rhinolophus ferrumequinum. Mol. Ecol. 9: 1131-1135. doi:10.1046/j.1365-294x.2000.00982.x. PMID:10964232.

Rossiter, S.J., Jones, G., Ransome, R.D., and Barratt, E.M. 2002. Relatedness structure and kin-biased foraging in the greater horseshoe bat (Rhinolophus ferrumequinum). Behav. Ecol. Sociobiol. 51: 510-518. doi:10.1007/s00265-002-0467-1.

Rozas, J., Librado, P., Sánchez-DelBarrio, J.C., Messeguer, X., and Rozas, R. 2009. DnaSP v5.10.00. Universita de Barcelona, Barcelona, Spain.

Sikes, R.S., and Gannon, W.L. 2011. Guidelines of the American Society of Mammalogists for the use of wild mammals in research. J. Mammal. 92: 235-253. doi:10.1644/10-MAMM-F-355.1.

Silvis, A., Ford, W.M., Britzke, E.R., and Johnson, J.B. 2014. Association, roost use and simulated disruption of Myotis septentrionalis maternity colonies. Behav. Proc. 103: 283-290. doi:10.1016/j.beproc.2014.01.016.

Silvis, A., Ford, W.M., and Britzke, E.R. 2015a. Day-roost tree selection by northern long-eared bats-What do non-roost tree comparisons and one year of data really tell us? Global Ecol. Conserv. 3: 756-763. doi:10.1016/j.gecco.2015. 03.008 .

Silvis, A., Ford, W.M., and Britzke, E.R. 2015b. Effects of hierarchical roost removal on northern long-eared bat (Myotis septentrionalis) maternity colonies. PLoS ONE, 10: e0116356. doi:10.1371/journal.pone.0116356. PMID:25611060.

Silvis, A., Abaid, N., Ford, W.M., and Britzke, E.R. 2016a. Responses of bat social groups to roost loss: more questions than answers. In Sociality in bats. Edited by J. Ortega. Springer International Publishing, Switzerland. pp. 261-280. doi:10.1007/978-3-319-38953-0.

Silvis, A., Perry, R., and Ford, W.M. 2016b. Relationships of three species of bats impacted by white-nose syndrome to forest condition and management. Gen. Tech. Rep. SRS-214, USDA Forest Service, Southern Research Station, Asheville, N.C.
Stow, A.J., Sunnucks, P., Briscoe, D.A., and Gardner, M.G. 2001. The impact of habitat fragmentation on dispersal of Cunningham's skink (Egernia cunninghami): evidence from allelic and genotypic analyses of microsatellites. Mol. Ecol. 10: 867-878. doi:10.1046/j.1365-294X.2001.01253.x. PMID:11348496.

Sueur, C., King, A.J., Conradt, L., Kerth, G., Lusseau, D., Mettke-Hofmann, C., Schaffner, C.M., Williams, L., Zinner, D., and Aureli, F. 2011. Collective decision-making and fission-fusion dynamics: a conceptual framework. Oikos, 120: 1608-1617. doi:10.1111/j.1600-0706.2011.19685.x.

Trune, D.R., and Slobodchikoff, C.N. 1976. Social effects of roosting on the metabolism of the pallid bat (Antrozous pallidus). J. Mammal. 57: 656-663. doi:10. 2307/1379437. PMID:1003044.

Van Oosterhout, C., Hutchinson, W.F., Wills, D.P.M., and Shipley, P. 2004. MICRO-CHECKER: software for identifying and correcting genotyping errors in microsatellite data. Mol. Ecol. Notes, 4: 535-538. doi:10.1111/j.1471-8286.2004.00684.x.

Veith, M., Beer, N., Kiefer, A., Johannesen, J., and Seitz, A. 2004. The role of swarming sites for maintaining gene flow in the brown long-eared bat (Plecotus auritus). Heredity, 93: 342-349. doi:10.1038/sj.hdy.6800509. PMID: 15241447.

Vonhof, M.J., Davis, C.S., Fenton, M.B., and Strobeck, C. 2002. Characterization of dinucleotide microsatellite loci in big brown bats (Eptesicus fuscus), and their use in other North American vespertilionid bats. Mol. Ecol. Notes, 2: 167-169. doi:10.1046/j.1471-8286.2002.00189.x.

Watkins, L.C., and Shump, K.A. 1981. Behavior of the evening bat Nycticeius humeralis at a nursery roost. Am. Midl. Nat. 105: 258-268. doi:10.2307| 2424744 .

Weir, B.S. 1996. Genetic data analysis II. Sinauer Associates, Inc., Sunderland, Mass.

Weir, B.S., and Cockerham, C.C. 1984. Estimating F-statistics for the analysis of population structure. Evolution, 38: 1358-1370. doi:10.2307/2408641. PMID: 28563791.

Wilde, C.J., Knight, C.H., and Racey, P.A. 1999. Influence of torpor on milk protein composition and secretion in lactating bats. J. Exp. Zool. 284: 35-41. doi:10.1002/(SICI)1097-010X(19990615)284:1<35::AID-JEZ6>3.0.CO;2-Z. PMID: 10368932.

Wilkinson, G.S. 1985. The social organization of the common vampire bat. Behav. Ecol. Sociobiol. 17: 111-121. doi:10.1007/BF00299243.

Wilkinson, G.S. 1992. Information transfer at evening bat colonies. Anim. Behav. 44: 501-518. doi:10.1016/0003-3472(92)90059-I.

Willis, C.K.R., and Brigham, R.M. 2004. Roost switching, roost sharing and social cohesion: forest-dwelling big brown bats, Eptesicus fuscus, conform to the fission-fusion model. Anim. Behav. 68: 495-505. doi:10.1016/j.anbehav.2003. 08.028.

Willis, C., and Brigham, R. 2007. Social thermoregulation exerts more influence than microclimate on forest roost preferences by a cavity-dwelling bat. Behav. Ecol. Sociobiol. 62: 97-108. doi:10.1007/s00265-007-0442-y.

Wilmer, J.W., Moritz, C., Hall, L., and Toop, J. 1994. Extreme population structuring in the threatened ghost bat, Macroderma gigas: evidence from mitochondrial DNA. Proc. R. Soc. B Biol. Sci. 257: 193-198. doi:10.1098/rspb.1994. 0115.

Zahn, A. 1998. Individual migration between colonies of Greater mouse-eared bats (Myotis myotis) in upper Bavaria. Z. Säugetierkd. 63: 321-328.

Zahn, A. 1999. Reproductive success, colony size and roost temperature in atticdwelling bat Myotis myotis. J. Zool. (Lond.), 247: 275-280. doi:10.1111/j.1469-7998. 1999.tb00991.x. 